\title{
TOURISM ECONOMICS RESEARCH: A REVIEW AND ASSESSMENT ${ }^{1}$
}

\author{
Haiyan Song \\ The Hong Kong Polytechnic University, Hong Kong \\ Larry Dwyer \\ University of New South Wales, Australia \\ Gang Li \\ Zheng Cao \\ University of Surrey, United Kingdom
}

\begin{abstract}
This paper aims to provide the most up-to-date survey of tourism economics research and to summarise the key trends in its recent development. Particular attention is paid to the research progress made over the last decade in respect of approaches, methodological innovations, emerging topics, research gaps, and directions for future research. Remarkable but unbalanced developments have been observed across different sub-research areas in tourism economics. While neoclassical economics has contributed the most to the development of tourism economics, alternative schools of thought in economics have also emerged in advancing our understanding of tourism from different perspectives. As tourism studies are multi- and inter-disciplinary, integrating economics with other social science disciplines will further contribute to knowledge creation in tourism studies.
\end{abstract}

Keywords: tourism economics, research integration, demand, supply, impact, and econometric model

\section{INTRODUCTION}

Tourism, despite the ongoing debates about its definition over the past decades, is commonly recognised as a human activity that defines the demand for and supply of its products and the usage of resources that may result in either positive or negative socioeconomic consequences at both national and international level. The significance of the economic approach and perspective to understanding this human activity is widely known. As far as both its demand and supply are concerned, tourism has distinct characteristics which set it apart from other economic activities (Stabler, Papatheodorou, \& Sinclair, 2010). Studying the characteristics of tourism from the economic perspective is a relatively new area of research pioneered by Guthrie (1961), Gerakis (1965), and Gray (1966). Propelled by the tremendous evolution of tourism as an economic activity over the past 50 years, there has also been a remarkable growth, in

\footnotetext{
${ }^{1}$ Please cite this article as: Song H, Dwyer L, Li G, CAO Z. (2012). Tourism Economics Research: A Review and Assessment. Annals of Tourism Research, 39 (3), pp. 1653-1682. http://dx.doi.org/10.1016/j.annals.2012.05.023
} 
terms of number of publications, in tourism economics research. This trend has been even more pronounced since the 1990s with the establishment of Tourism Economics, a scientific journal devoted entirely to the publications of research outputs in this field. More recently, the publication of key texts on the economics of tourism, such as Dwyer, Forsyth, and Dwyer (2010), Stabler et al. (2010), and Tribe (2011), has marked the maturity of tourism economics as a field of study comprising comprehensive bodies of knowledge and theoretical foundations in the context of tourism.

The dynamics of tourism, as an activity and as an industry, call for continuous efforts in seeking new approaches, tools, and perspectives in order to acquire new knowledge and a greater understanding of the discipline. Therefore, it is both necessary and useful to comprehensively review the development of the research field in terms of where we were, where we are, and where we should be. Very few such endeavours have been made in this regard. Eadington and Redman's (1991) work represents the earliest attempt to provide an overview of the developments in tourism economics. Key research areas identified in his review include demand elasticities and their modelling techniques, market structure and ownership, economic impacts, and policies. His recommendations for further research were in such directions as inter-sectoral linkages, the integration of economic models and statistical techniques for demand analysis, and the development of national and regional input-output (I-O) models for economic impact assessment. Sinclair (1998) surveys the literature over a period of two decades, highlighting some new developments, such as the system-of-equation approach to demand analysis and computable general equilibrium (CGE) modelling for economic impact assessment. These developments echo Eadington and Redman's (1991) earlier recommendations. Tremblay (1998) focuses his review on different perspectives on industrial organisation and recommends institutional and network approaches. In addition, Sinclair (1998) directs scholars' attention to the environmental issues related to sustainable tourism development. She highlights the fact that impact analysis was limited to the use of I-O tables, with CGE models receiving little attention, and the neglect of taxation and regulatory policy in relation to environmental issues. In another review, Sinclair, Blake and Sugiyarto (2003) argue that research in tourism economics has been dominated by demand analysis, while little attention has been paid to the determinants of tourism supply, including different forms of tourism business integration. More recently, Dwyer, Forsyth, and Papatheodorou (2011) have provided an overview of the state of research and the key developments in tourism economics, including perspectives on the implications for research of the recent global financial crisis. In their reviews, Li, Song, and Witt (2005) and Song and Li (2008) mainly concentrate on the methodological developments in tourism demand studies.

This paper aims to provide the most up-to-date survey of tourism economics research, highlighting recent developments and likely future directions. Drawing on the latest publications up to the end of 2011, mainly from key tourism journals such as Annals of Tourism Research, Tourism Economics, Tourism Management, and the Journal of Travel Research, this review tracks the historical developments in each of the key research areas, paying particular attention to the research progress made over the last decade in terms of economic approaches, methodological innovations, emerging topics, and directions for future research. 


\section{DEMAND}

Demand analysis has the longest history in tourism economics research and has undergone remarkable developments in terms of diversity of interests, depth of theoretical foundations, and advances in research methods ( $\mathrm{Li}$, Song, and Witt, 2005). Its dominant position, noted by Sinclair et al. (2003), is still observable in the latest developments in tourism economics. Based on the latest empirical evidence, the following section focuses on the issues in demand analysis that have emerged since the publication of previous review (e.g., Li et al., 2005; Song \& Li, 2008).

\section{Demand and its Determinants}

The theoretical argument of tourism demand under neoclassical economic theory usually assumes a multi-stage budgeting process. Two pillars of the assumption are the composite commodity theorem and the separability of preferences. The composite commodity theorem states that various commodities can be aggregated to broad bundles of products, provided that prices within a bundle move in parallel. The separability of preferences means preferences within one bundle can be described independently of those in another one (Smeral \& Weber, 2000). In the tourism context, such a multistage process implies that a typical tourist will firstly allocate the total budget over several time periods, then separate the goods into leisure goods and other consumption goods, and further choose among domestic trips, international travels and other activities within the leisure goods bundle. In the last stage, the destination country/region is determined. It is also noted by Smeral and Weber (2000) that the decision at each stage can be thought of as corresponding to a utility maximization problem of its own, where the income effect and price effect are implicated in empirical models.

Tourism demand is predominantly measured by the number of arrivals and the level of tourist expenditure (receipts), along with their variations, in per capita terms (Song, Witt, \& Li, 2009; Song, Li, Witt, \& Fei, 2010). One alternative measure, the number of tourist nights (length of stay), has appeared in recent studies. For example, Gokovali, Bahar, and Kozak (2007), Martinez-Garcia and Raya (2008), and Barros and Machado (2010) adopt survival analysis (duration model) based on Lancaster's characteristics framework to examine the determinants of this measure.

According to the demand theory, the pivotal factors shaping a tourist's budget line are the income of the consumer and the price of the tourism product/service. Specifically, in empirical tourism demand studies, the income of origin country/region, the own price of a destination, and the substitute prices of alternative destinations are the most commonly considered determinants (Song, Witt, \& Li, 2009). Demand elasticities are thus of particular significance, and these have been one of the focuses of the published studies on demand analysis. The latest development is to construct confidence intervals for demand elasticity estimates using the bias-corrected bootstrap method (Song, Kim, \& Yang, 2010). This method overcomes the limitation of the traditional point estimates, which neglect the degree of variability and are thus less informative.

An additional variable that affects tourists' decisions (though not linked to the budget line) is the marketing expenditure of the tourism product/service provider (at both 
destination level and firm level). However, the difficulty in accessing the relevant marketing data hinders its application in most empirical studies (Kulendran \& Dwyer, 2009; Zhang, Kulendran, \& Song, 2010). The magnitude of the effect of marketing expenditure has been found to be as low as several hundredths.

Beyond the neoclassical theory, Lancaster's (1966) characteristics framework explores the individual's consumption of specific features/attributes, through which he/she attains satisfaction and utility. Applications of the hedonic pricing approach in the context of tourism demand mainly focus on the prices of tour packages (e.g., Sinclair, Clewer, \& Pack, 1990; Aguilo, Alegre, \& Riera, 2001; Papatheodorou, 2002; Thrane, 2005; Chen \& Rothschild, 2010). The public good components (e.g., cultural legacy, public safety, and public infrastructure) embedded in tourism products have been considered in recent studies (e.g., Rigall-I-Torrent \& Fluvia, 2007, 2011). The difficulties faced in using this approach include the selection of the appropriate explanatory variables and the potential multicollinearity problem among the variables (Chen \& Rothschild, 2010; Sinclair et al., 1990).

\section{Methodological Developments}

Since the 1990s, demand modelling studies have shifted from the use of static regression models to a range of sophisticated dynamic specifications. Dynamics in tourism demand are often accounted for by repeat visits, word-of-mouth recommendations, time lags in implementing a decision, information asymmetry, supply rigidities, and long-term adjustments (Morley, 2009). A recent development in dynamic modelling is the integration of the time-varying-parameter (TVP) technique and the causal structural time series model (Song, Li, Witt, \& Athanasopoulos, 2011), which combines the technical advantages of both methods and shows superior forecasting performance. Recently, a new cointegration-error correction method-the bound test of Pesaran, Shin, and Smith (2001) — has been applied to tourism (e.g., Halicioglu, 2010; Song, Lin, Witt, \& Zhang, 2011). This is a test to detect the long-run co-integration relationship among variables in a demand model. Its advantage lies in its ability to accommodate variables with different integration orders.

Developments in system-of-equations approaches, such as the vector autoregressive model (VAR) and the almost ideal demand system (AIDS), have expanded the dimensions of investigations. These approaches overcome the limitations of the singleequation methods by bringing solid theoretical foundations to tourism demand modelling and forecasting exercises. The AIDS model, designed to analyse the interdependence of budget allocations and different consumer goods/services, has received much attention over the past decade. The dynamic forms of AIDS, coupled with the error correction mechanism and TVP technique, represent the latest development of system-of-equation methods. Their applications shed new light on the substitution and complementary effects between destinations (e.g., Cortes-Jimenez, Durbarry, \& Pulina, 2009; Li, Song, \& Witt, 2006) or between consumption categories (Wu, Li, \& Song, 2011, 2012) and destination competitiveness (Mangion, Durbarry, \& Sinclair, 2005). VAR models have received relatively little attention in tourism until recently (e.g., Song \& Witt, 2006; Seetanah \& Khadaroo, 2009; Torraleja, Vazquez, \& Franco, 2009). Panel data analysis techniques have not been widely applied in tourism demand research with only a few exceptions (e.g., Ledesma-Rodriguez, Navarro-Ibanez, 
\& Perez-Rodriguez, 2001; Naude \& Saayman, 2005; Garin-Munoz, 2009; Seetaram, 2010). Future studies should pay more attention to the dynamic version of panel data analysis and to more advanced estimation methods such as the fully modified Ordinary Least Square estimator (Pedroni, 2004).

In addition to selecting the best specified models for modelling and forecasting tourism demand, identifying the key economic determinants of tourism demand, calculating the demand elasticities, and evaluating the forecasting performance of the demand models are the key research tasks in tourism demand studies. The conclusion based on the empirical evidence is that no single model can consistently outperform others on all occasions (Song \& Li, 2008). Recent literature thus suggests combining the forecasts from different models with a view to improving forecasting accuracy (Shen, $\mathrm{Li}$, \& Song, 2011; Wong, Song, Witt, \& Wu, 2007): Shen et al. (2011) use six linear combination methods; Cang (2011) introduces the nonlinear alternatives; and Chan, Witt, Lee, and Song (2010) employ programming approaches to determine the weights of combination. These empirical studies generally provide favourable evidence of forecast combination. In addition, Coshall and Charlesworth (2011) argue that many forecasting scenarios involve more than a single goal and advocate the use of goal programming, which can accommodate multiple criteria decision making.

The growth cycle of tourism demand (Butler (1980) has received increasing research attention. One of its methodological developments is to employ Markov regime switching models to test the tourism lifecycle concept.According to this concept, a destination goes through six key stages: exploration, involvement, development, consolidation, stagnation, and decline and/or rejuvenation. The three-stage Markovswitching process is particularly in line with the lifecycle concept, as it allows for a period of decline, slow growth, and rapid growth. In addition, it implicitly allows for rejuvenation. This approach is applied by Moore and Whitehall (2005) to the context of inbound tourism in Barbados. Empirical evidence suggests that the lifecycle concept provides an adequate explanation of the growth stages for each market.

\section{Interdependence and Interrelation}

Associated with globalization, market interdependence has become an emerging topic in the latest demand studies. Tourism demand in one destination tends to be affected by demand for alternative destinations due not only to cultural and environmental similarities and geographic proximity, but also to similarity in the economic determinants that underpin destination choice. The interactions between tourist flows and their determinants at different destinations shape tourists' behaviours when they decide where to travel.

In light of the turbulence in the world economy over the past decade, efforts have been made to address the interdependence of tourism demands, although the number of published studies is still limited. These studies often firstly confirm the co-movements of tourism demand in different destinations using the co-integration technique and then use VAR models to test for the cause-effect relationships among these demand variables of the destinations under consideration via the Granger causality test (Granger, 1969). Torraleja et al. (2009) and Seo, Park, and Boo (2010) identify the existence of causal relationships between the tourism demand variables across different destinations. In particular, Seo, Park, and Yu (2009) recognise the time varying rather than the constant 
conditional correlations in their study and examine the determinants of conditional correlations among destinations using the VAR model. The results reveal that the industrial production index and the real exchange rate are the key determinants of tourism demand in all of the destinations studied.

One of the problems with the existing literature on the interdependence of tourism demand is the lack of attention paid to economic foundations. The studies usually adopt the series of tourist arrivals itself and conduct analysis based only on its time series properties and omit the important economic indicators in the specifications of the models. Another issue is that the number of destinations under discussion is relatively small (usually four or five) and their selection tends to be ad hoc, which limits the scope of the analysis. The small destinations system may overlook the endogenous effects of variables that are not included in the models. Future studies should consider a theoretically justified demand system involving a large number of interactive destinations using appropriate econometric modelling techniques, such as the Global VAR modelling system (Pesaran et al., 2004).

\section{FIRM, INDUSTRY, AND MARKET}

Economic studies of tourism supply are complex and cover a diverse range of topics from the firm level to the industry and market level. Over the period 1970s-1990s, there was vigorous debate about whether tourism is an industry or a market when it is studied from a supply perspective (e.g., Leiper, 1990, 1992; Smith, 1988, 1991). In the recent tourism economics literature, it has been commonly recognised that tourism is neither a single industry nor a single market (Dwyer et al., 2010; Stabler et al., 2010). Tourism is a composite product that involves a combination of a variety of goods and services provided by different sectors, such as transport, accommodation, tour operators, travel agencies, visitor attractions, and retailing. Moreover, tourism products are serviced and transacted in different markets. Therefore, tourism can be studied using both industrybased and market-based economic tools (Wilson, 1998).

Drawing its theoretical foundation from industrial economics or industrial organisation, the development of tourism supply research follows that of industrial economics. The neoclassical approach dominated the development of industrial economics until the late 1970s. The structure-conduct-performance (SCP) paradigm provides a useful framework for studying tourism supply from a market perspective. Earlier schools of thought, such as the Austrian school, evolutionary economics, and institutional economics, were developed to relax the restrictions of the neoclassical assumptions, such as rational preferences, information symmetry, static equilibria, and profit maximisation. In particular, the dynamic nature of the market and its institutional arrangements emphasised by these newer approaches is highly relevant to the operations of tourism businesses. By introducing game theory to the study of the firm and the market, new industrial economics has been developed, and this provides powerful tools for analysing firms' strategic relationships, particularly in the context of a supply chain (Stabler et al., 2010; Song, 2011).

\section{The Structure-Conduct-Performance (SCP) Paradigm}

Based on the neoclassical economic theory, especially different market structure models, the SCP paradigm suggests that the type of the market structure within which a 
firm operates (e.g., monopolistic, monopolistically competitive, or oligopolistic) rigidly determines a firm's conduct (e.g., output decisions, pricing behaviour, and innovation), which ultimately affects its overall performance (e.g., its efficiency, profitability, and growth) (Mason, 1939; Bain, 1956). In the further development of this paradigm, multiple feedback effects and causation flows were taken into account (Scherer \& Ross, 1990; Shepherd, 1990). A number of empirical studies have tested the SCP paradigm in tourism, predominantly in the accommodation sector (e.g., Davies, 1999; Davies \& Downward, 1996; Pan, 2005) but also in the restaurant sector (e.g., Jang, 2011). However, the findings are inconclusive, due largely to the different empirical settings and methods used. Davies (1999) and Pan (2005) both suggest that market structure directly influences the performance of a firm, with no clear intermediate effects between market structure and conduct. However, Cunill and Forteza (2010) find that a franchising strategy contributes to increasing market concentration by hotel chains. Tung, Lin, and Wang (2010) reveal a bidirectional causal relationship between the market structure and strategic behaviour based on a more advanced simultaneous equation model.

Although a number of tourism supply studies at the market or industry level do not exactly follow the SCP framework, their research focuses fall into one of the following three groups.

Structure. Among all market structure models, oligopoly has attracted the most attention in the literature, such as the studies by Baum and Mudambi (1994) on the UK fully inclusive tour industry, Davies (1999) on the UK hotel industry, Baum and Mudambi (1995) on the resort hotel industry in Bermuda, Bresson and Logossah (2011) on the cruising sector in the Caribbean, and Ciliberto and Tamer (2009) on the American airline industry. In these studies, the common characteristics of oligopoly are identified in tourism markets in which a small number of large firms dominate the markets, which leads to both high market concentration and fixed costs due to entry barriers.

Conduct. Firms' conduct, particularly pricing behaviour, has been well studied under certain market structures, especially oligopoly. For instance, Vila and Córcoles (2011) investigate such pricing strategies as dynamic pricing and price discrimination between flag carriers and low-cost airlines. Abrate, Capriello, and Fraquelli (2011) examine the effects of quality signals on price setting in the hotel industry based on the hedonic pricing approach. Poater and Garriga (2009) reveal that the price discrimination and peak-load pricing settings that are often exercised in the airline industry are also evident in some European hotels. Based on firm-level time-series data, Malighetti, Paleari, and Redondi (2010) find that the overall intensity of Ryanair's dynamic pricing has decreased. The discussions of firms' pricing behaviour are often related to yield management issues. Other research on conduct includes various growth strategies such as mergers and acquisitions (e.g., Vogel, 2009), innovation investment (e.g., Fernández, Cala, \& Domecq, 2011), and diversification (Andreu, Claver, \& Quer, 2009). In their recent review article, Williams and Shaw (2011) stress the importance of globalisation and innovation strategies and their relationships.

Performance. Firm performance, particularly measured by productivity and efficiency, has been a long-standing topic in tourism supply studies. The hotel sector has attracted the most attention, followed by travel agents and restaurants. Research developments in 
this direction are mostly related to methodological advancement. The empirical literature on tourism firm efficiency has been dominated by a non-parametric approach — the data envelopment analysis (DEA) (e.g., Barros \& Alves, 2004; Chiang, Tsai, \& Wang, 2004). The main advantages of DEA compared to the standard econometric technique are that it 1) does not require any form of functional specification and 2) is able to handle multiple inputs and outputs readily in any (in)efficiency theoretical paradigm (Bernini \& Guizzardi, 2010). Based on the input and output data from DEA, a Malmquist Index can be constructed to measure productivity change. The criticism of the DEA method is related to its potential statistical shortcomings. A further development of this method is to use the bootstrap approach to obtain statistical properties. This method has been applied to tourism firms by Assaf, Barros, and Machado (2011).

Another well-developed method is the stochastic frontier approach (a parametric approach). Its principal advantage lies in the decomposition of deviations from the efficiency levels between noise (stochastic error) and pure efficiency; however, it faces the challenge of determining the appropriate functional forms (Barros \& Dieke, 2008). Recently, a semi-parametric method which combines non-parametric and parametric approaches was applied to tourism firms by Bernini, Freo, and Gardini (2004). Furthermore, Assaf (2010) employs a Bayesian panel stochastic frontier model to study the cost efficiency of Australian airports.

In addition to efficiency and productivity, firms' long-term growth is also used to measure firm performance. Based on the production function (i.e., input-output), significant input factors are identified to explain the growth (e.g., Smeral, 2009a). This line of research departs from the SCP paradigm and does not seek explanations of firm growth from market structure or conduct (e.g., Cunill \& Forteza, 2010; Jang, 2011).

\section{Game Theory and Supply Chain}

To overcome the limitations of the original static form of the SCP paradigm, game theory provides a more powerful tool and a dynamic approach to analysing situations in which the decisions of multiple economic actors affect each other's payoff. As such, game theory deals with economic actors' interactive optimisation problems and interfirm relationships (Cachon \& Netessine, 2004). The game-theoretical approach is useful for analysing the strategic decisions of firms within the same industry, particularly in an oligopolistic market, such as tour operators at a destination (e.g. Zhang, Heung, \& Yan, 2009). Recent studies emphasize inter-firm strategic interactions in the context of tourism supply chains (Zhang, Song, \& Huang, 2009; Song, 2011). The gametheoretical approach has been employed to study the interactions among tourism supply chain members and their strategic options, such as price competition and coordination between a theme park and a tour operator (Song, Yang, \& Huang, 2009); relationships among a theme park, hotels, and tour operators in a context of package holiday supplies (Huang, Chen, Song, \& Zhang, 2010); and cooperation and competition between two supply chains (Yang, Huang, Song, \& Liang, 2009).

Although a range of games have been developed, their applications to tourism supply are mostly restricted to non-cooperative deterministic games and involve simplistic strategy options in abstract experimental situations instead of actual industries. Further 
applications should consider other types of games, such as cooperative, repeated, differential, signalling and screening, and Bayesian games, especially in their dynamic forms (Cachon \& Netessine, 2004). More useful managerial implications will be drawn if more realistic market environments are considered in the developed models.

\section{Institutional Approach to the Behaviour of Firms}

Moving away from the neoclassical perspective, the institutional approach (such as transaction-cost and agency theories) regards the firm as a governance structure instead of a production entity (Coase, 1960; Jensen \& Meckling, 1976). Agency theory recognises conflicts of interest between different economic actors and deals with the problems resulting from the principal-agent relationship, such as adverse selection and moral hazards (Stabler et al., 2010). Transaction cost economics adopts a contractual approach to the existence of the firm and focuses on the efficiency of making transactions internally compared to the cost of making such transactions through the market mechanism (Williamson, 1975).

Despite its usefulness, this approach has not been widely used in analysing the behaviour of tourism firms. Guilding, Warnken, Ardill, and Fredline (2005) discuss the condominium owner-manager relationship in the Australian tourism context based on agency theory. Hojman and Hiscock (2010) interpret the failure of a festival organisation as being the result of ill-defined property rights, leading to increased transaction costs, incomplete information from an unreliable source, and free riding. Gurcaylilar-Yenidogan, Yenidogan, and Windsperger (2011) explain the completeness of contracts using the transaction cost theory in the context of tour operator-hotel allotment contracts. Future research could apply agency and transaction cost theories to analyse inter-firm behaviour, such as within a tourism supply chain, or in the context of service outsourcing or integration between firms. In addition, tourism firm analysis should also apply new institutional theories such as the steward theory, which better recognises the relevance of cooperation and coordination to inter-firm relationships rather than opportunistic behaviours, as the agency theory suggests (Donaldson, 1990). This is in line with the network approach advocated by Tremblay (1998).

\section{Industry Agglomeration and Clustering}

The new economic geography, or geographical economics, provides another useful perspective for inter-firm relationships in the context of tourism. For example, industry agglomeration and industry clustering are concerned with the economic importance of geographic location (Marshall, 1920; Porter, 1998). The benefits of agglomeration economies include minimising distance, transportation and production costs, obtaining cheap labour, and minimising risks (Dicken \& Lloyd, 1990). Similarly, cluster theory suggests that interconnectedness through industry clustering is the source of growth, innovation, and competitiveness (Porter, 1998). Industry agglomeration and clustering (sometimes, the term "networking" is also used) has become an emerging topic in recent tourism supply studies. For example, Novelli, Schmitz, and Spencer (2006) examine tourism industry networks and clusters in relation to innovation in the UK. Bernini (2009) examines the meeting and convention industry in Italy and addresses the importance of convention destination clustering and networking. Zhang, Qu, and Guo (2011) focus on the agglomeration of China's convention industry. The latter two 
studies are both based on the econometric approach, providing statistical evidence on the sources of agglomeration and clustering.

In addition to the above topics, a number of other classical supply issues, such as production cost, labour supply, and competition-related policy concerns, have appeared in the tourism economics literature from time to time. Due to space constraints, they are excluded from this review. The imbalance of tourism supply analyses among different sub-sectors should be noted. Hotels, airlines, and tour operators have received more attention than visitor attractions, travel agencies, and other forms of transport. Some research gaps can also be observed with regard to the applications of more recently developed theories of the firm or the market. For instance, the knowledge-based view of the firm, which regards a firm as a knowledge-creating entity, has not been explicitly applied in tourism. This view moves beyond the resource-based theory of the firm, arguing that "knowledge and the capability to create and utilise such knowledge are the most important source of a firm's sustainable competitive advantage" (Nonaka, Toyama, $\&$ Nagata, 2000, p. 1). Tourism supply analysis would benefit from the application of these modern industrial economics theories.

\section{MACROECONOMICS OF DESTINATIONS}

From a macroeconomic perspective, tourism contributes to local, national, and international economic developments as well as destination competitiveness. This has important policy implications.

\section{The Economic Impact}

Given its important policy implications, the economic contribution of tourism and changes in it resulting from external shocks to the tourism system, such as specific events and policies, has been a popular topic in tourism economics research over the last few decades. The development of tourism impact studies can be seen from both its methodological advancement and the development of its supportive statistical tools. The former is evidenced by the applications of Keynesian-type multipliers (e.g., Archer, 1977), cost-benefit analysis (CBA) (Abelson 2011), I-O models (e.g., Archer \& Fletcher, 1996; Frechtling \& Horvath, 1998), the social accounting matrix (SAM) method as a further extension of the I-O method (e.g., Wagner, 1997), and computable general equilibrium (CGE) frameworks (e.g., Blake, 2009; Dwyer, Forsyth, Spurr, \& Vanho, 2003; Pratt, 2011). The latest development of statistical tools to support economic contribution analysis involves tourism satellite accounts (TSAs). As noted by Frechtling and Smeral (2010), modern time series econometrics also contributes to impact analysis, especially the impacts of mega events (e.g., intervention models, combined with outlier detection).

Impact Analysis Methods. Among the various impact analysis methods, the use of Keynesian multipliers is the most simplistic, while the CGE approach is the most sophisticated. A CGE model consists of a number of equations describing the key relationships within an economy. The mathematical specification abides by microeconomic optimisation principles (Stabler et al., 2010). Therefore, the CGE approach has its theoretical foundation in neoclassical microeconomics. 
Each of the above methods relies on certain economic assumptions and thus has its limitations. The CGE approach, as the latest, most complete and comprehensive method, was developed to overcome some of the restrictive assumptions that the I-O method embodies, such as exogeneity of the determinants of demand, perfectly elastic aggregate supply curve, and infinite or zero substitution effects (Dwyer et al., 2010). CGE models recognise that an expanding tourism industry tends to "crowd out" other sectors of economic activity. The extent of these "crowding out" effects depends on factor constraints, changes in the exchange rate, the workings of labour markets, and the macroeconomic policy context. It has been noted that the multipliers calculated based on CGE models are much more modest, while the I-O method tends to overestimate the economic effects (Dwyer, Forsyth, \& Spurr, 2006). However, as with any other method, the CGE approach inevitably relies on some assumptions which may possibly be restrictive (Stabler et al., 2010). For instance, standard CGEs often assume constant returns to scale in production functions and ignore market failures (Croes \& Severt, 2007). The assumption of fixed real wages and flexible unemployment, and the assumption of fixed unemployment and flexible wages, which can be both incorporated into a CGE model, may give a range of possible outcomes in relation to the crowding out effects (Dwyer et al., 2006). Nevertheless, the merits of the CGE approach compared to other methods are generally accepted.

Increasing attention has been paid to the applications of CGE models to the estimation of (a) the economic impacts of demand shocks occasioned by events such as foot and mouth disease (Sinclair et al., 2003), the World Cup (Lee, Moon, \& Mjelde, 2010), the Olympics (Li, Blake, \& Cooper, 2011), and a terrorist attack (Pambudi, McCaughey, \& Smyth, 2009) and (b) the effects on tourism of policies such as taxation (e.g., Gago, Labandeira, Picos, \& Rodríguez, 2009; Gooroochurn \& Sinclair, 2005), tourism crisis management (Blake \& Sinclair, 2003), and international trade policies (e.g., Sinclair et al., 2003). It should be noted that there are two types of impact studies based on CGE models and demand forecasting models, respectively. The former estimate the economic effects of demand shocks not only within the tourism industry but also in other related economic sectors (Adams \& Parmenter, 1995), while the latter (e.g., Smeral, 2009b; Song, Lin, Witt, \& Zhang, 2011) focus on the impact on tourism demand only. Often the results of the latter are employed in the CGE simulation process (e.g., Lee et al., 2010).

The latest methodological development focuses on dynamic CGE models. Most of the CGE models applied to tourism impact studies since the mid-1990s have been comparative static models, which only provide a snapshot of economic relationships at one point in time; the adjustment process from one equilibrium to another is ignored. Dynamic CGE models introduce a time dimension in various forms to take account of the dynamics in an economic system. Blake (2009) employs a dynamic CGE model to demonstrate the different effects of an increase in tourism demand under different dynamic conditions. Further developments of dynamic CGE models, such as consideration of the effects of different market structure models on pricing behaviours, are still required (Blake, 2009).

In contrast to economic impact analysis, $\mathrm{CBA}$ is the most comprehensive of the economic appraisal techniques. $\mathrm{CBA}$ is particularly important in the context of 
evaluating tourism policy, programmes, regulations, projects, and developments. CBA considers the costs and benefits to society as a whole to determine whether a particular change will make society better or worse off. This requires estimating a wider range of costs and benefits than those included in a financial appraisal, including the estimation of values where no direct price is charged. Surprisingly, despite the progress in terms of the concepts and applications of CBA in the economics literature, this area is relatively neglected in tourism economics (Abelson, 2011; Dwyer et al., 2010).

TSAs. The robustness of economic impact assessment relies heavily on the quality and completeness of data support. To meet this need, a statistical accounting framework-a TSA-based on the internationally adopted concepts, principles, and structure of the System of National Accounts has been developed (Diakomihalis \& Lagos, 2011; Frechtling, 2010). Since TSAs focus on direct effects only, they tend to underestimate the overall economic contribution of tourism. Therefore, adjustments for indirect effects and intermediate consumption are needed (Smeral, 2006).

A new direction in TSA-based impact analysis is to integrate an estimation of carbon emissions into a TSA framework so that a more complete assessment of tourism impact, including both economic and environmental dimensions, can be made in a consistent fashion. If the relationship between industry production and greenhouse gas emissions is known, then it is possible to calculate the emissions which are due to tourism as measured by the TSA.

Pioneering studies in this direction include Jones and Munday (2007) and Dwyer, Forsyth, Spurr, and Hoque (2010). The development of TSA frameworks needs to be further extended to the sub-national level, which still lacks a standardised conceptual framework (Frechtling, 2010).

While a TSA represents an important information base for the estimation of the economic contribution of changes in tourism demand, it is not in itself a modelling tool for economic impact assessment. A TSA measures the economic contribution of tourism, that is, the size and overall significance of the industry within an economy. In contrast, economic impact refers to the changes in the economic contribution resulting from specific events or activities that comprise "shocks" to the tourism system. This should not be confused with the contribution itself. Economic impact implies that the overall change in the economic contribution must take account of any interactive effects which occur across the economy and thus requires a model to provide the simulations (Dwyer, Forsyth, \& Spurr, 2007).

Where the required secondary data support is unavailable for an economic impact analysis, primary data collection from survey sampling is probably the only way forward (e.g., Alcover et al., 2011; Lacher \& Nepal, 2010; Southwick, Bergstrom, \& Wall, 2009). This approach can provide useful information where more sophisticated methods are not applicable, but the results should be used with caution due to sampling biases. Careful statistical treatments with the raw data are also needed (Southwick et al., 2009). 
The Employment Effect. In addition to the income effect which dominates economic impact analyses, the employment effect is another well established research area, dating back to the 1970s (e.g., Diamond, 1974, 1977). The focus has shifted from the level of tourism employment, input-output analysis and the multiplier effect (Dwyer \& Forsyth, 1998) to the quality and structure of employment (e.g., Sinclair, 1990, 1997), particularly the gender wage gap (e.g., Campos-Soria, Ortega-Aguaza, \& Ropero-Garcia, 2009; Munoz-Bullon, 2009). These discussions provide useful policy implications in relation to poverty alleviation, labour immigration, and education (Riley \& Szivas, 2009; Lillo-Bañuls \& Casado-Diaz, 2010). With regard to the methodology of wage-related empirical studies, the traditional OLS method has been criticised and more appropriate alternatives are now employed, such as a two-limit Tobit model (Muñoz-Bullón, 2009) and instrumental variables techniques (Lillo-Bañuls \& Casado-Díaz, 2010). In the latter case, the authors present different findings from those based on the OLS method.

Most tourism employment studies have their theoretical foundation in neoclassical labour economics, such as the marginal productivity theory of demand. There has been little evidence that tourism labour and employment studies apply alternative approaches, especially the multidisciplinary approaches developed and promoted in the mainstream labour economics field (Spencer, 2011), such as new institutional labour economics, which draws on insights from sociology and political science (Osterman, 2009). New economic perspectives are needed to contribute to a fuller understanding of a wider range of labour and employment issues in tourism, such as employer-employee relationships, human resource issues, and the transformation of work within modern society.

\section{Tourism and Economic Growth}

With the growing importance of tourism to many economies, especially lessdeveloped ones, the relationship between tourism and economic growth has become one of the main research themes in recent literature. Proponents of the tourism-led growth (TLG) hypothesis emphasise that international tourism can bring foreign exchange, generate employment, spur local investments, exploit economies of scale, and diffuse technical knowledge (Schubert, Brida, \& Risso, 2011). Since the early 1990s, researchers have borrowed international trade models to investigate (typically within a small open economy setting) the effects of tourism on national welfare theoretically (e.g., Copeland, 1991; Hazari \& Sgro, 1995) and, more recently, the macroeconomic effects of a temporary demand shock (e.g., Hazari \& Sgro, 1995, 2004; Schubert \& Brida, 2009).

Meanwhile, the implications of a growing economy for tourism development also concern researchers. Smeral (2003) develops a theoretical framework in which structural change in demand ('demand bias'), after saturation in basic needs is achieved, drives tourism growth at a faster pace than that of the whole economy, whereas the productivity gap between tourism and manufacturing ('productivity bias') renders that tourism services become more expensive than manufactured goods in the long run, and the share of employment in the hotel and restaurant industry increases.

Researchers are also keen to find empirical evidence on whether tourism does relate to economic growth. However, the results have been inconclusive. The TLG hypothesis 
is generally tested by regressing GDP (or GDP growth) on tourism receipts (or arrivals) and real exchange rates. A prevailing practice is to test for the Granger causality between economic variables using the VAR model (e.g., Balaguer \& Cantavella-Jorda, 2002; Belloumi, 2010; Kim, Chen, \& Jang, 2006; Schubert et al., 2011) or panel data analysis (e.g., Narayan, Narayan, Prasad, \& Prasad, 2010; Seetanah, 2011). Many studies confirm a unidirectional causality running from international tourism to real GDP in specific countries/regions, while some find evidence of bidirectional relationships (e.g., Kim et al., 2006). Conversely, a few studies fail to detect a cointegration relationship and suggest that the TLG hypothesis does not hold in the studied case (e.g., Katircioglu, 2009).

Highlighting the role of capital formation, an emerging strand of studies argue that the mechanism underlying tourism's welfare-promoting effect follow the so-called TKIG hypothesis (tourism exports $\rightarrow$ capital goods imports $\rightarrow$ growth; see Nowak, Sahli, \& Cortes-Jimenez, 2007). The empirical models usually resemble those for the TLG hypothesis, with the variable of imports of industrial machinery included. The Johansen technique of co-integration and Granger causality tests are used to examine the interactions between variables. The findings are, however, mixed. Nowak et al. (2007) yield supportive evidence for both the TLG and TKIG hypotheses for Spain, whereas Cortes-Jimenez, Nowak, and Sahli (2011) only detect a short-run TKIG mechanism for Tunisia.

A straightforward implication would be that tourism does not always increase economic welfare. In fact, since the very early literature, researchers have noted that a tourism boom may lead to "de-industrialisation" in other sectors (Copeland, 1991). The phenomenon is often termed the "Dutch Disease effect". Focusing on a small island economy, Nowak and Sahli (2007) show that increased inbound tourism may lead to net welfare losses when tourism products are intensive users of coastal land. On the empirical side, Holzner (2011) examines a set of panel data for 134 countries over a period of 38 years. Although no signs of a contraction of the manufacturing sector are found in the long run, the author warns that the danger of the Dutch Disease effect could still be valid in the short or medium run.

The main criticisms faced by the TLG and TKIG studies related to their reliance on the use of the Granger causality test. In fact, the Granger causality test only represents the secessionist's view of causation (i.e., some economic activities precede others) and does not necessarily suggest the real cause-effect relationship (Stock \& Watson, 2003, p21).

\section{International Economics}

As a significant form of international trade flows, tourism inherently lies within the scope of international economics studies. As summarized by Zhang and Jensen (2007), trade theories can be extensively applied to explaining the service trade. The price competition among destinations and tourists' pursuit of sun, sand, sea or cultural heritage are reflections of the difference in destinations' technology/productive efficiency (Ricardo theory) and that in the natural endowments (Heckscher-Ohlin model). In the meantime, pilgrim tourism can be explained by similarity in preferences (e.g., cultural affinity), as in the Linder model. Strands of the new trade theories that 
capture the ownership advantages, innovation/diffusion patterns and agglomeration give an account of recent trends such as international hotel chains, internet marketing and tourism clusters.

From an empirical perspective, although concepts such as trade volume and exchange rate are readily considered in tourism demand modelling, their underlying relationships have been under-researched. Using the Granger causality test, a number of studies find supportive evidence of the bidirectional causality between international tourism and international trade (e.g., Santana-Gallego, Ledesma-Rodriguez, \& Perez-Rodriguez, 2011; Kulendran \& Wilson, 2000; Wong \& Tang, 2010). An exception is Khan, Toh, and Chua's (2005) study, which detects rare Granger causality between tourism and trade in the case of Singapore.

Foreign direct investment (FDI) is also linked to tourism, but the lack of comprehensive data has bedevilled researchers. On the basis of the data available, FDI in tourism actually remains quite low compared to FDI in other sectors. Endo (2006) argues that this is because many transnational corporation hotels use the non-equity forms of entry, resulting in no record in the FDI statistics. Some other researchers focus their attention on overall FDI, investigating the causal link between tourism and FDI (e.g., Sanford \& Dong, 2000; Tang, Selvanathan, \& Selvanathan, 2007), but again this suffers from the problem of reliance on the Granger causality test.

As regards exchange rate, its microeconomic role in deciding tourism demand has been well documented. However, few have investigated it at the macro level. Following Gil-Pareja, Llorca-Vivero, and Martinez-Serrano's (2007) examination of the effect of the Economic and Monetary Union of the European Union on tourism, Santana-Gallego, Ledesma-Rodriguez, and Perez-Rodriguez (2010) conduct an extensive panel analysis on the impact of an exchange rate regime on tourism and find that less flexible exchange rates are more favourable to tourism.

\section{Destination Competitiveness}

Destination competitiveness has stimulated continuous research (Crouch \& Ritchie, 2012). It has been defined from various angles and measured by different methodologies. The most comprehensive conceptual framework has been crafted by Crouch and Ritchie (1994, 2003). This framework incorporates such key elements as comparative and competitive advantages, macro and micro environments, and core and supporting resources. Crouch (2011) evaluates 36 competitiveness attributes with "expert" judgment to develop an insight into the importance of each attribute. Other researchers focus on specific destinations or particular aspects of competitiveness (e.g., Dwyer, Forsyth, \& Rao, 2000; Mangion et al., 2005; Ribes, Rodríguez, \& Jiménez, 2011). With most studies being concerned with the competitive position, however, few have paid attention to its (economic) return. Croes (2011) is among the exceptions that take account of the change in economic value when constructing the competitiveness model.

\section{ENVIRONMENTAL ISSUES}

The environmental issues of tourism are more complex than those in many other industries. Tourism production and consumption both have either positive or negative 
environmental consequences. Meanwhile, tourism activities are often affected by the quality of environmental resources (Tribe, 2011). The relationships between tourism and the natural environment are also distinct in comparison to those in manufacturing industries, where the environment is mainly viewed as an input factor of production. In the tourism industry, the environment is not only an input factor (e.g., water and energy), but also a key component of its output, such as national parks and agritourism (Razumova, Lozano, \& Rey-Maquieira, 2009).

\section{Environmental Research at Micro and Macro Levels}

The increasing attention being paid globally to sustainable tourism and climate change has led to growing research and debates on the environmental issues of tourism, particularly over the last decade. At the micro level, the effects of the environment on both the demand for and the supply of tourism have been addressed. The topics associated with demand for tourism include the impact of overcrowding on visitation (Santana-Jiménez \& Hernández, 2011), weather variations on demand for skiing (Shih, Nicholls, \& Holecek, 2009), and the influence of natural environment conditions on holiday destination choice (Huybers \& Bennett, 2000). These studies are commonly based on tourism demand models and incorporate environmental factors as explanatory variables in a demand function. The topics relating to the supply of tourism are often to do with the pricing strategy of nature reserves (Becker, 2009), the economic incentives to undertake voluntary environmental management (Blanco, Rey-Maquieira, \& Lozano, 2009), and firms' environmental strategies and economic performance (Claver-Cortés, Molina-Azorín, Pereira-Moliner, \& López-Gamero, 2007; González \& León, 2001).

At the macro level, attention has been paid to the assessment of the environmental impacts of and on tourism. For example, Berrittella, Bigano, Roson, and Tol (2006) study the economic implications of climate-change-induced changes for tourism demand based on a CGE model. Kytzia, Walz, and Wegmann (2011) examine the impact of tourism development on land use efficiency based on regional augmented I-O tables. As discussed in the previous section, one of the latest developments is to combine the economic and environmental dimensions into the same framework using TSAs. To address the concern of tourism sustainability, an even more complete tourism impact assessment framework including economic, social, environmental, and institutional dimensions has been proposed by Fernandes and Sanchez Rivero (2009), and a composite index is created. Such a system will be useful for monitoring a destination's sustainable development and comparing the competitiveness among destinations provided that the indicators are carefully chosen.

\section{Valuation of Environmental Resources}

Environmental issues are often discussed in relation to market failure. As market prices do not reflect the full social costs or benefits related to the use of natural resources, overuse of these resources, worsening environmental conditions, overcrowding, and congestion problems merge. Lack of property rights, public goods, and externalities are common explanations of the market failure associated with the environmental impacts of tourism (Dwyer et al., 2010). In order to make more effective use of these natural resources and pursue a more sustainable path of development, governments and communities need to understand the total economic value of their resources and implement appropriate policies. 
Four practical methods for estimating the non-market value of an environmental amenity have been developed and applied in tourism-related contexts: contingent valuation and contingent choice methods, which are both associated with state preferences, and hedonic pricing and travel cost methods, which are both based on revealed preference techniques. The state preference methods are more straightforward since the willingness-to-pay amounts can be easily obtained or calculated through a survey process (e.g., Bostedt \& Mattsson, 1995; Snyder \& Smail, 2009; Tapsuwan, Burton, \& Perriam, 2010). However, the limitations of these methods associated with hypothetical bias (i.e., the respondent's stated value of willingness to pay and the actual behaviour) have been well recognised. Given its foundation on Lancaster's "characteristics" approach to consumer theory, the hedonic pricing method is the most theoretically rigorous. Its validity depends on the extent to which the price of a tourism product is determined by its environmental attributes. Its applications in tourism are few, with Baddeley's (2004) study being an exception. The travel cost method focuses on the influence of distance on the demand to visit an environmental amenity (e.g., Hesseln, Loomis, Gonzalez-Caban, \& Alexander, 2003; Park, Bowker, \& Leeworthy, 2002); however, it cannot be used to assess the non-use value. As each of the above methods has certain limitations (Dwyer et al., 2010; Stabler et al., 2010), careful consideration should be given to the choice of the most appropriate alternative or combination of alternatives. The evaluation results based on traditional methods should be used with great caution, especially when their aim is to inform certain policy making.

\section{Environmental Policy and Governance}

To control and reduce the adverse effects of tourism on the environment and to achieve more sustainable development of tourism, especially at nature-based destinations, increasing scholarly attention has been given to discussions about the appropriate instruments for environmental governance. Neoclassical environmental economics conforms to the principle that market mechanisms will solve the environmental issues. Based on this principle, price-based instruments are advocated to internalise adverse environmental impacts, lower tourism capacity, and increase longterm societal welfare. For instance, Lozano, Gómez, and Rey-Maquieira (2008), Piga (2003), and Schubert (2010) propose theoretical models based on partial or general equilibrium frameworks to support overnight-stay tax, tourism tax in general (payable by tourists), and land-use tax, respectively.

Non-price instruments, such as government regulations and industry voluntary management, as well as semi-price instruments such as quotas have also been discussed in the tourism literature. A positive view has been proposed regarding environmental regulations and management leading to the improved competitiveness of firms or the destination. In a tourism context, Razumova et al. (2009) argue the validity of the Porter hypothesis, which states that efficient environmental regulation may improve both environmental quality and domestic firms' international competitiveness (Porter, 1991). Razumova et al. (2009) stress that given the distinct nature of the tourism industry and its products, "the findings of works on different sectors cannot be applied in a straightforward manner to the tourism sector" (p. 387). The positive demand effects of environmental regulation and management are more relevant to the tourism industry. Huybers and Bennett (2003) illustrate the above view in an empirical study through 
simulations of a model of imperfect competition. Moreover, Blanco et al. (2009) explore the validity of firms' voluntary environmental management and collective voluntary actions as alternative environmental policies.

In future studies on the environmental issues of tourism, particularly the implications of tourism development for environmental policy and governance, a new institutional approach should be considered, as suggested by Blanco et al. (2009). Advocated by ecological economists, the new institutional ecological economics highlights the interdependence among environmental resource users which can be used to characterise environmental problems and to design institutional responses. Institutional ecological economics also acknowledges the positive transaction costs of the institutional design of governance solutions. In addition, theories of institutional change and social capital will be useful for explaining the change in environmental governance institutions (Paavola \& Adger, 2005). This direction of environmental studies has yet to be explored by tourism economists.

\section{CONCLUDING REMARKS}

Through half a century's research endeavours, tourism economics has made substantial developments and has contributed significantly to knowledge creation in the broad tourism field. The special characteristics of tourism products call for new perspectives and approaches beyond the conventional economic principles applied to other industries. The research developments among various sub-subject areas are unbalanced.

Demand analysis continues to dominate tourism economics studies in terms of research interests and methodological advancements. In addition to continuous endeavours in seeking more powerful statistical tools to assist new insights, further research attention should be paid to the interrelationships among international tourism demand through a more complete system which accounts for the endogeneity among the economic variables. Supply studies are diverse and often fragmented. Comparably fewer methodological innovations have been observed, but alternative approaches (e.g., agency theory and transition cost economics) to the neoclassical philosophy and crossdisciplinary perspectives (e.g., new economic geography) have emerged. Further studies should aim for a more comprehensive understanding of the complex relationships between tourism organisations, both within and across sectors, in modern tourism supply and the corresponding firm behaviour. The more advanced game theoretical approach is welcome, particularly in the context of supply chains.

At the macro level, assessment of the economic impacts of tourism development continues to be a central focus, although it will take a long time for this field of research to reach its methodological maturity. Further advancements in research on the relationship between tourism development and economic development should not ignore the theoretical foundation of such studies. In the context of the increasing attention paid to sustainability, environmental issues have attracted increasing research interest. Methodological limitations with regard to environmental impact assessment and the valuation of environmental resources deserve careful attention given the policy implications of these types of research. Studies on environmental governance need to take account of the different perspectives on this issue. Due to space constraints, this 
review is unable to give a full coverage of the developments of tourism economics research. Many aspects and issues have been omitted, regrettably.

Overall, the economic approach, especially the neoclassical economic theories, has contributed to a better understanding of tourism. Alternative economic perspectives such as new institutional economics will help to extend the boundaries of our knowledge. In the wider context of tourism knowledge creation, economics should continue to play a significant role along with other social science disciplines. The earlier observation that "many tourism researchers seem unwilling to reach across disciplinary and methodological boundaries" (Echtner \& Jamal, 1997, p. 869) must be avoided. As Tribe and Xiao (2011) note, "tourism is gradually evolving from a multidisciplinary endeavor into an interdisciplinary stage of research and scholarship" (p. 22). Integrating economics with other social sciences will not only advance our understanding of tourism, but also enrich the development of tourism economics. To pursue this direction, collective effort is necessary.

\section{References}

Abelson, P. (2011). Evaluating major events and avoiding the mercantilist fallacy. Economic Papers, 30(1), 48-59.

Abrate, G., Capriello, A., \& Fraquelli, G. (2011). When quality signals talk: Evidence from the Turin hotel industry. Tourism Management, 32, 912-921.

Adams, P. D., \& Parmenter, B. R. (1995). An applied general equilibrium analysis of the economic effects of tourism in a quite small, quite open economy. Applied Economics, 27(10), 985-994.

Aguilo, E., Alegre, J., \& Riera, A. (2001). Determinants of the price of German tourist packages on the island of Mallorca. Tourism Economics, 7(1), 59-74.

Alcover, A., Alemany, M., Jacob, M., Payeras, M., Garcia, A., \& Martinez-Ribes, L. (2011). The economic impact of yacht charter tourism on the Balearic economy. Tourism Economics, 17(3), 625-638.

Andreu, R., Claver, E., \& Quer, D. (2009). Type of diversification and firm resources: New empirical evidence from the Spanish tourism industry. International Journal of Tourism Research, 11, 229-239.

Archer, B. (1977). Tourism Multipliers: The State of the art. Occasional Papers in Economics, no. 11. Bangor: University of Wales Press.

Archer, B., \& Fletcher, J. (1996). The economic impact of tourism in the Seychelles. Annals of Tourism Research, 23(1), 32-47.

Assaf, A. (2010). The cost efficiency of Australian airports post privatisation: A Bayesian methodology. Tourism Management, 31, 267-273.

Assaf, A. G., Barros, C. P., \& Machado, L. P. (2011). The future outlook for Portuguese travel agents. Tourism Economics, 17(2), 405-423.

Baddeley, M. C. (2004). Are tourists willing to pay for aesthetic quality? An empirical assessment from Krabi Province, Thailand. Tourism Economics, 10(1), 45-61.

Bain, J. S. (1956). Barriers to New Competition. Cambridge MA: Harvard University Press.

Balaguer, J., \& Cantavella-Jorda, M. (2002). Tourism as a long-run economic growth factor: The Spanish case. Applied Economics, 34, 877-884. 
Barros, C. P., \& Alves, P. (2004). Productivity in tourism industry. International Advances in Economic Research, 10, 215-225.

Barros, C. P., \& Dieke, P. U. C. (2008). Technical efficiency of African hotels. International Journal of Hospitality Management, 27, 438-447.

Barros, C. P., \& Machado, L. P. (2010). The length of stay in tourism. Annals of Tourism Research, 37(3), 692-706.

Baum, T., \& Mudambi, R. (1994). A Ricardian analysis of the fully inclusive tour industry. The Service Industries Journal, 14(1), 85-93.

Baum, T., \& Mudambi, R. (1995). An empirical analysis of oligopolistic hotel pricing. Annals of Tourism Research, 22(3), 501-516.

Becker, N. (2009). A comparative analysis of the pricing systems of nature reserves. Tourism Economics, 15(1), 193-213.

Belloumi, M. (2010). The relationship between tourism receipts, real effective exchange rate and economic growth in Tunisia. International Journal of Tourism Research, $12,550-560$.

Bernini, C. (2009). Convention industry and destination clusters: Evidence from Italy. Tourism Management, 30, 878-889.

Bernini, C., Freo, M., \& Gardini, A. (2004). Quantile estimation of frontier production function. Empirical Economics, 29(2), 373-381.

Bernini, C., \& Guizzardi, A. (2010). Internal and locational factors affecting hotel industry efficiency: Evidence from Italian business corporations. Tourism Economics, 16(4), 883-913.

Berrittella, M., Bigano, A., Roson, R., \& Tol, R. S. J. (2006). A general equilibrium analysis of climate change impacts on tourism. Tourism Management, 27(5), 913-924.

Blake, A. (2009). The dynamics of tourism's economic impact. Tourism Economics, 15(3), 615-628.

Blake, A. T., \& Sinclair, M. T. (2003). Tourism crisis management: US response to September 11. Annals of Tourism Research, 30(4), 813-832.

Blanco, E., Rey-Maquieira, J., \& Lozano, J. (2009). Economic incentives for tourism firms to undertake voluntary environmental management. Tourism Management, $30(1), 112-122$.

Bostedt, G., \& Mattsson, L. (1995). The value of forests for tourism in Sweden. Annals of Tourism Research, 22(3), 671-680.

Bresson, G., \& Logossah, K. (2011). Crowding-out effect of cruise tourism on stay-over tourism in the Caribbean: Non-parametric panel data evidence. Tourism Economics, 17(1), 127-158.

Butler, R. (1980). The concept of a tourism area cycle of evolution: Implications for management resources. The Canadian Geographer, 24(1), 5-16.

Cachon, G. P., \& Netessine, S. (2004). Game theory in supply chain analysis. In D. Simchi-Levi, S. D. Wu, \& Z. M. Shen (Eds.), Handbook of Quantitative Supply Chain Analysis: Modeling in the E-Business Era. Boston, MA: Kluwer Academic Publishers.

Campos-Soria, J. A., Ortega-Aguaza, B., \& Ropero-Garcia, M. A. (2009). Gender segregation and wage difference in the hospitality industry. Tourism Economics, 15(4), 847-866.

Cang, S. (2011). A non-linear tourism demand forecast combination model. Tourism Economics, 17(1), 5-20. 
Chan, C. K., Witt, S. F., Lee, Y. C. E., \& Song, H. (2010). Tourism forecast combination using CUSUM technique. Tourism Management, 31, 891-897.

Chen, C., \& Rothschild, R. (2010). An application of hedonic pricing analysis to the case of hotel rooms in Taipei. Tourism Economics, 16(3), 685-694.

Chiang, W., Tsai, M., \& Wang, L. S. (2004). A DEA evaluation of Taipei hotels. Annals of Tourism Research, 31(3), 712-715.

Ciliberto, F., \& Tamer, E. (2009). Market structure and multiple equilibria in airline markets. Econometrica, 77(6), 1791-1828.

Claver-Cortés, E., Molina-Azorín, J. F., Pereira-Moliner, J., \& López-Gamero, M. D. (2007). Environmental strategies and their impact on hotel performance. Journal of Sustainable Tourism, 15, 663-679.

Coase, R. H. (1960). The problem of social cost. Journal of Law and Economics, 3, 144.

Copeland, B. R. (1991). Tourism, welfare and de-industrialization in a small open economy. Economica, 58(232), 515-529.

Cortes-Jimenez, I., Durbarry, R., \& Pulina, M. (2009). Estimation of outbound Italian tourism demand: A monthly dynamic EC-LAIDS model. Tourism Economics, $15(3), 547-565$.

Cortes-Jimenez, I., Nowak, J., \& Sahli, M. (2011). Mass beach tourism and economic growth: Lessons from Tunisia. Tourism Economics, 17(3), 531-547.

Coshall, J. T., \& Charlesworth, R. (2011). A management oriented approach to combination forecasting of tourism demand. Tourism Management, 32, 759-769.

Croes, R. (2011). Measuring and explaining competitiveness in the context of small island destinations. Journal of Travel Research, 50(4), 431-442.

Croes, R. R., \& Severt, D. E. (2007). Evaluating short-term tourism economic effects in confined economies - Conceptual and empirical considerations. Tourism Economics, 13(2), 289-307.

Crouch, G., \& Ritchie, J. B. R. (1994). Destination competitiveness: Exploring foundations for a long-term research program. Proceedings of the Administrative Sciences Association of Canada Annual Conference, Halifax, Nova Scotia, June 25-28, 1994, 79-88.

Crouch, G. I. (2011). Destination competitiveness: An analysis of determinant attributes. Journal of Travel Research, 50(1), 27-45.

Crouch, G., \& Ritchie, J. R. B. (2006). Competitiveness and Tourism. In L. Dwyer \& P. Forsyth (Eds.), International Handbook on the Economics of Tourism (pp. 419433). Cheltenham: Edward Elgar Publishing.

Cunill, O. M., \& Forteza, C. M. (2010). The franchise contract in hotel chains: A study of hotel chain growth and market concentrations. Tourism Economics, 16(3), 493-515.

Davies, B. (1999). Industrial organization - The UK hotel sector. Annals of Tourism Research, 26(2), 294-311.

Davies, B., \& Downward, P. (1996). The structure, conduct, performance paradigm as applied to the UK hotel industry. Tourism Economics, 2, 151-158.

Diakomihalis, M. N., \& Lagos, D. G. (2011). An empirical approach to coastal leisure shipping in Greece and an assessment of its economic contribution. Tourism Economics, 17(2), 437-456.

Diamond, J. (1974). International tourism and the developing countries: A case study in failure. Economica Internazionale, 27(3-4), 601-615. 
Diamond, J. (1977). Tourism's role in economic development: The case re-examined. Economic Development and Cultural Change, 25(3), 539-553.

Dicken, P., \& Lloyd, P. E. (1990). Location in Space: Theoretical Perspectives in Economic Geography. New York: HarperCollins Publishers.

Donaldson, L. (1990). The ethereal hand: Organizational economics and management theory. Academy of Management Review, 15, 369-381.

Dwyer, L., \& Forsyth, P. (1998). Estimating the employment impacts of tourism to a nation. Tourism Recreation Research, 23(2), 3-12.

Dwyer, L., Forsyth, P., \& Dwyer, W. (2010). Tourism Economics and Policy. Bristol: Channel View Publications.

Dwyer, L., Forsyth, P., \& Rao, P. (2000). The price competitiveness of travel and tourism: A comparison of 19 destinations. Tourism Management, 21(1), 9-22.

Dwyer, L., Forsyth, P., \& Spurr, R. (2006). Assessing the economic impacts of events: A computable general equilibrium approach. Journal of Travel Research, 45(1), 59-66.

Dwyer, L., Forsyth, P., \& Spurr, R. (2007). Contrasting the uses of TSAs and CGE models: Measuring tourism yield and productivity. Tourism Economics, 13(4), 537-551.

Dwyer, L., Forsyth, P., Spurr, R., \& Vanho, T. (2003). Tourism's contribution to a state economy: A multi-regional general equilibrium analysis. Tourism Economics, 9(4), 431-448.

Dwyer, L., Forsyth, P., Spurr, R., \& Hoque, S. (2010). Estimating the carbon footprint of Australian tourism. Journal of Sustainable Tourism, 18(3), 355-366.

Dwyer, L., Forsyth, P., \& Papatheodorou, A. (2011). Economics of Tourism, Contemporary Tourism Reviews. Series Editor: C. Cooper. Oxford: Goodfellow.

Eadington, W. R., \& Redman, M. (1991). Economics and tourism. Annals of Tourism Research, 18, 41-56.

Echtner, C. M., \& Jamal, T. B. (1997). The disciplinary dilemma of tourism studies. Annals of Tourism Research, 24(4), 868-883.

Endo, K. (2006). Foreign direct investment in tourism - Flows and volumes. Tourism Management, 27, 600-614.

Fernandez, J. I. P., Cala, A. S., \& Domecq, C. F. (2011). Critical external factors behind hotels' investments in innovation and technology in emerging urban destinations. Tourism Economics, 17(2), 339-357.

Frechtling, D. C. (2010). The tourism satellite account: A primer. Annals of Tourism Research, 37(1), 136-153.

Frechtling, D., \& Horvath, E. (1998). Estimating the multiplier effects of tourism expenditures on a local economy through a regional input-output model. Journal of Travel Research, 37(4), 324-332.

Frechtling, D., \& Smeral, E. (2010). Measuring and interpreting the economic impact of tourism: 20-20 hindsight and foresight. In D. G. Pearce \& R. W. Butler (Eds.), Tourism Research: A 20-20 vision (pp.67-79). Oxford, England: Goodfellow Publishing.

Gago, A., Labandeira, X., Picos, F., \& Rodríguez, M. (2009). Specific and general taxation of tourism activities. Evidence from Spain. Tourism Management, 30, 381-392.

Garin-Munoz, T. (2009). Tourism in Galicia: Domestic and foreign demand. Tourism Economics, 15(4), 753-769. 
Gerakis, A. S. (1965). Effects of exchange-rate devaluations and revaluations on receipts from tourism. International Monetary Fund Staff Papers, 12, 365-384.

Gil-Pareja, S., Llorca-Vivero, R., \& Martinez-Serrano, J. A. (2007). The effect of EMU on tourism. Review of International Economics, 15(2), 302-312.

Gokovali, U., Bahar O., \& Kozak, M. (2007). Determinants of length of stay: A practical use of survival analysis. Tourism Management, 28(3), 736-746.

González, M., \& León, C. J. (2001). The adoption of environmental innovations in the hotel industry of Gran Canaria. Tourism Economics, 7, 117-190.

Gooroochurn, N., \& Sinclair, M. T. (2005). Economics of tourism taxation: Evidence from Mauritius. Annals of Tourism Research, 32(2), 478-498.

Gray, H. P. (1966). The demand for international travel by United States and Canada. International Economic Review, 7, 83-92.

Granger, C. W. J. (1969). Investigating causal relationships by econometric models and cross spectral methods. Econometrica, 37, 424-438.

Guilding, C., Warnken, J., Ardill, A., \& Fredline, L. (2005). An agency theory perspective on the owner/manager relationship in tourism-based condominiums. Tourism Management, 26(3), 409-420.

Gurcaylilar-Yenidogan, T., Yenidogan, A., \& Windsperger, J. (2011). Antecedents of contractual completeness: The case of tour operator-hotel allotment contracts. Procedia - Social and Behavioral Sciences, 24, 1036-1048.

Guthrie, H. W. (1961). Demand for tourists' goods and services in a world market. Papers and Proceedings of the Regional Science Association, 7, 159-175.

Halicioglu, F. (2010). An econometric analysis of the aggregate outbound tourism demand of Turkey. Tourism Economics, 16(1), 83-97.

Hazari, B. R., \& Sgro, P. M. (1995). Tourism and growth in a dynamic model of trade. The Journal of International Trade \& Economic Development, 4(2), 243-252.

Hazari, B. R., \& Sgro, P. M. (2004). Tourism, Trade and National Welfare. Amsterdam: Elsevier.

Hesseln, H., Loomis, J. B., Gonzalez-Caban, A., \& Alexander, S. (2003). Wildfire effects on hiking and biking demand in New Mexico: A travel cost study. Journal of Environmental Management, 69, 359-368.

Hojman, D. E., \& Hiscock, J. (2010). Interpreting suboptimal business outcomes in light of the Coase theorem: Lessons from Sidmouth International Festival. Tourism Management, 31, 240-249.

Holzner, M. (2011). Tourism and economic development: The beach disease? Tourism Management, 32, 922-933.

Huang, G. Q., Chen, W., Song, H., \& Zhang, X. (2010). Game-theoretic study of the dynamics of tourism supply chains for package holidays under quantity competition. Tourism Economics, 16(1), 197-216.

Huybers, T., \& Bennett, J. (2000). Impact of the environment on holiday destination choices of prospective UK visitors: Implications for Tropical North Queensland. Tourism Economics, 6(1), 21-46.

Huybers, T., \& Bennett, J. (2003). Environmental management and the competitiveness of nature-based tourism destinations. Environmental and Resources Economics, 24(3), 213-233.

Jang, S. (2011). Growth-focused or profit-focused firms: Transitions toward profitable growth. Tourism Management, 32, 667-674. 
Jensen, M. C., \& Meckling, W. (1976). Theory of the firm: Managerial behavior, agency costs, and ownership structure. Journal of Financial Economics, 3(4), 305-360.

Jones, C., \& Munday, A. (2007). Tourism satellite accounts and impact assessments: Some considerations. Tourism Analysis, 13(1), 53-69.

Katircioglu, S. T. (2009). Revisiting the tourism-led-growth hypothesis for Turkey using the bounds test and Johansen approach for cointegration. Tourism Management, 30, 17-20.

Khan, H., Toh, R. S., \& Chua, L. (2005). Tourism and trade: Cointegration and Granger causality tests. Journal of Travel Research, 44, 171-176.

Kim, H. J., Chen, M., \& Jang, S. (2006). Tourism expansion and economic development: The case of Taiwan. Tourism Management, 27, 925-933.

Kulendran, N., \& Dwyer, L. (2009). Measuring the return from Australian tourism marketing expenditure. Journal of Travel Research, 47, 275-284.

Kulendran, N., \& Wilson, K. (2000). Is there a relationship between international trade and international travel? Applied Economics, 32, 1001-1009.

Kytzia, S., Walz, A., \& Wegmann, M. (2011). How can tourism use land more efficiently? A model-based approach to land-use efficiency for tourist destinations. Tourism Management, 32, 629-640.

Lacher, R. G., \& Nepal, S. K. (2010). Dependency and development in northern Thailand. Annals of Tourism Research, 37(4), 947-968.

Lancaster, K. J. (1966). A new approach to consumer theory. Journal of Political Economy, 84, 132-157.

Ledesma-Rodriguez, F. J., Navarro-Ibanez, M., \& Perez-Rodriguez, J. V. (2001). Panel data and tourism: A case study of Tenerife. Tourism Economics, 7(1), 75-88.

Lee, C., Moon, S., \& Mjelde, J. W. (2010). Disentangling the effects on the Korean economy of the 9/11 terrorist attacks from the short-run effects of hosting the 2002 World Cup, using the CGE model. Tourism Economics, 16(3), 611-628.

Leiper, N. (1990). Partial industrialization of tourism systems. Annals of Tourism Research, 17, 600-605.

Leiper, N. (1992). Industrial entropy in tourism systems. Annals of Tourism Research, 19, 600-605.

Li, G., Song, H., \& Witt, S. F. (2005). Recent developments in econometric modeling and forecasting. Journal of Travel Research, 44(1), 82-89.

Li, G., Song, H., \& Witt, S. F. (2006). Time varying parameter and fixed parameter linear AIDS: An application to tourism demand forecasting. International Journal of Forecasting, 22, 57-71.

Li, S., Blake, A., \& Cooper, C. (2011). Modelling the economic impact of international tourism on the Chinese economy: A CGE analysis of the Beijing 2008 Olympics. Tourism Economics, 17(2), 279-303.

Lillo-Bañuls, A., \& Casado-Diaz, J. M. (2010). Rewards to education in the tourism sector: One step ahead. Tourism Economics, 16(1), 11-23.

Lozano, J., Gomez, C. M., \& Rey-Maquieira, J. (2008). The TALC hypothesis and economic growth theory. Tourism Economics, 14(4), 727-749.

Malighetti, P., Paleari, S., \& Redondi, R. (2010). Has Ryanair's pricing strategy changed over time? An empirical analysis of its 2006-2007 flights. Tourism Management, 31, 36-44. 
Mangion, M., Durbarry, R., \& Sinclair, M. T. (2005). Tourism competitiveness: Price and quality. Tourism Economics, 11(1), 45-68.

Marshall, A. (1920). Principles of Economics. London: MacMillan and Co.

Martinez-Garcia, E., \& Raya, J. M. (2008). Length of stay for low-cost tourism. Tourism Management, 29(6), 1064-1075.

Mason, E. S. (1939). Price and production policies of large scale enterprises. American Economic Review, 29, 61-74.

Moore, W., \& Whitehall, P. (2005). The tourism area lifecycle and regime switching models. Annals of Tourism Research, 32(1), 112-126.

Morley, C. L. (2009). Dynamics in the specification of tourism demand models. Tourism Economics, 15(1), 23-39.

Munoz-Bullon, F. (2009). The gap between male and female pay in the Spanish tourism industry. Tourism Management, 30, 638-649.

Narayan, P. K., Narayan, S., Prasad, A., \& Prasad, B. C. (2010). Tourism and economic growth: A panel data analysis for pacific island countries. Tourism Economics, 16(1), 169-183.

Naude, W. A., \& Saayman, A. (2005). Determinants of tourist arrivals in Africa: A panel data regression analysis. Tourism Economics, 11(3), 365-391.

Nonaka, I., Toyama, R., \& Nagata, A. (2000). A firm as a knowledge-creating entity: A new perspective on the theory of the firm. Industrial and Corporate Change, 9(1), 1-20.

Novelli, M., Schmitz, B., \& Spencer, T. (2006). Networks, clusters and innovation in tourism: A UK experience. Tourism Management, 27(6), 1141-1152.

Nowak, J., \& Sahli, M. (2007). Coastal tourism and 'Dutch disease' in a small island economy. Tourism Economics, 13(1), 49-65.

Nowak, J., Sahli, M., \& Cortes-Jimenez, I. (2007). Tourism, capital good imports and economic growth: theory and evidence for Spain. Tourism Economics, 13(4), 515-536.

Osterman, P. (2009). The contours of institutional labour economics: Notes towards a revived discipline. Socio-Economic Review, 7(4), 695-708.

Paavola, J., \& Adger, W. N. (2005). Institutional ecological economics. Ecological Economics, 53(3), 353-368.

Pambudi, D., McCaughey, N., \& Smyth, R. (2009). Computable general equilibrium estimates of the impact of the Bali bombing on the Indonesian economy. Tourism Management, 30, 232-239.

Pan, C. M. (2005). Market structure and profitability in the international tourist hotel industry. Tourism Management, 26, 845-850.

Papatheodorou, A. (2002). Exploring competitiveness in Mediterranean resorts. Tourism Economics, 8(2), 133-150.

Park, T., Bowker, J. M., \& Leeworthy, V. R. (2002). Valuing snorkeling visits to the Florida Keys with stated and revealed preference models. Journal of Environmental Management, 65(3), 301-312.

Pedroni, P. (2004). Panel cointegration: Asymptotic and finite sample properties of pooled time series tests with an application to the PPP hypothesis. Econometric Theory, 20, 597-625.

Pesaran, M. H., Shin, Y., \& Smith, R. J. (2001). Bounds testing approaches to the analysis of level relationships. Journal of Applied Econometrics, 16, 289-326.

Pesaran, M. H., Schuermann, T., \& Weiner, S. M. (2004). Modeling regional 
interdependencies using a global error-correcting macroeconometric model. Journal of Business and Economic Statistics, 22(1), 129-162

Piga, C. A. (2003). Territorial planning and tourism development tax. Annals of Tourism Research, 30(4), 886-905.

Poater, A., \& Garriga, A. (2009). Tourism in European cities: Insights into the dynamics of weekend hotel accommodation. Tourism Economics, 15(1), 41-86.

Porter, M. E. (1991). America's green strategy. Scientific American, 264(4), 96.

Porter, M. E. (1998). Clusters and the new economics of competition. Harvard Business Review, 76(6), 77-90.

Pratt, S. (2011). Economic linkages and impacts across the TALC. Annals of Tourism Research, 38(2), 630-650.

Razumova, M., Lozano, J., \& Rey-Maquieira, J. (2009). Is environmental regulation harmful for competitiveness? The applicability of the Porter hypothesis to tourism. Tourism Analysis, 14(3), 387-400.

Ribes, J. F. P., Rodríguez, A. R., \& Jiménez, M. S. (2011). Determinants of the competitive advantage of residential tourism destinations in Spain. Tourism Economics, 17(2), 373-403.

Rigall-I-Torrent, R., \& Fluvia, M. (2007). Public goods in tourism municipalities: Formal analysis, empirical evidence and implications for sustainable development. Tourism Economics, 13(3), 361-378.

Rigall-I-Torrent, R., \& Fluvia, M. (2011). Managing tourism products and destinations embedding public goods components: A hedonic approach. Tourism Management, 32, 244-255.

Riley, M., \& Szivas, E. (2009). Tourism employment and poverty: Revisiting the supply curve. Tourism Economics, 15(2), 297-305.

Ritchie, J. R., \& Crouch, G. I. (2003). The Competitive Destination: A Sustainable Tourism Perspective. Wallingford: CABI Publishing.

Sanford, D. M., \& Dong, H. (2000). Investment in familiar territory: Tourism and new foreign direct investment. Tourism Economics, 6(3), 205-219.

Santana-Gallego, M., Ledesma-Rodriguez, F. J., \& Perez-Rodriguez, J. V. (2010). Exchange rate regimes and tourism. Tourism Economics, 16(1), 25-43.

Santana-Gallego, M., Ledesma-Rodriguez, F. J., \& Perez-Rodriguez, J. V. (2011). Tourism and trade in small island regions: The case of the Canary islands. Tourism Economics, 17(1), 107-125.

Santana-Jimenez, Y., \& Hernandez, J. M. (2011). Estimating the effect of overcrowding on tourist attraction: The case of Canary Islands. Tourism Management, 32(2), 415-425.

Scherer, F. M., \& Ross, D. (1990). Industrial Market Structure and Economics Performance. Boston, MA: Houghton Mifflin Company.

Schubert, S. F. (2010). Coping with externalities in tourism: A dynamic optimal taxation approach. Tourism Economics, 16(2), 321-343.

Schubert, S. F., \& Brida, J. G. (2009). Macroeconomic effects of changes in tourism demand: A simple dynamic model. Tourism Economics, 15(3), 591-613.

Schubert, S. F., Brida, J. G., \& Risso, W. A. (2011). The impacts of international tourism demand on economic growth of small economies dependent on tourism. Tourism Management, 32, 377-385.

Seetanah, B. (2011). Assessing the dynamic economic impact of tourism for island economies. Annals of Tourism Research, 38(1), 291-308. 
Seetanah, B., \& Khadaroo, J. (2009). An analysis of the relationship between transport capital and tourism development in a dynamic framework. Tourism Economics, 15(4), 785-802.

Seetaram, N. (2010). Use of dynamic panel cointegration approach to model international arrivals to Australia. Journal of Travel Research, 49(4), 414-422.

Seo, J. H., Park, S. Y., \& Boo, S. (2010). Interrelationships among Korean outbound tourism demand: Granger causality analysis. Tourism Economics, 16(3), 597610.

Seo, J. H., Park, S. Y., \& Yu, L. (2009). The analysis of the relationships of Korean outbound tourism demand: Jeju island and three international destinations. Tourism Management, 30, 530-543.

Shen, S., Li, G., \& Song, H. (2011). Combination forecasts of international tourism demand. Annals of Tourism Research, 38(1), 72-89.

Shepherd, W. G. (1990). The Economics of Industrial Organization ( ${ }^{\text {rd }}$ ed.). Englewood Cliffs, NJ: Prentice-Hall.

Shih, C., Nicholls, S., \& Holecek, D. F. (2009). Impact of weather on downhill ski lift ticket sales. Journal of Travel Research, 47(3), 359-372.

Sinclair, M. T. (1990). Tourism Development in Kenya. Washington, DC: World Bank.

Sinclair, M. T. (1997). Issues and theories of gender and work in tourism. In M. T. Sinclair (Ed.), Gender, Work and Tourism. London: Routledge.

Sinclair, M. T. (1998). Tourism and economic development: A survey. Journal of Development Studies, 34(5), 1-15.

Sinclair, M. T., Blake, A., \& Sugiyarto, G. (2003). The economics of tourism. In C. Cooper (Ed.), Classic Reviews in Tourism (pp. 22-54). Clevedon: Channel View Publications.

Sinclair, M. T., Clewer, A., \& Pack, A. (1990). Hedonic prices and the marketing of package holidays: The case of tourism resorts in Malaga. In G. Ashworth \& B. Goodall (Eds.), Marketing of Tourism Places (pp. 85-103). London: Routledge.

Smeral, E. (2003). A structural view of tourism growth. Tourism Economics, 9(1), 7793.

Smeral, E. (2006). Tourism satellite accounts: A critical assessment. Journal of Travel Research, 45(1), 92-98.

Smeral, E., \& Weber, A. (2000). Forecasting international tourism trends to 2010. Annals of Tourism Research, 27(4), 982-1006.

Smeral, E. (2009a). Growth accounting for hotel and restaurant industries. Journal of Travel Research, 47(4), 413-424.

Smeral, E. (2009b). The impact of the financial and economic crisis on European tourism. Journal of Travel Research, 48(1), 3-13.

Smith, S. L. J. (1988). Defining tourism: A supply-side view. Annals of Tourism Research, 15, 179-190.

Smith, S. L. J. (1991). The supply-side definition of tourism: Reply to Leiper. Annals of Tourism Research, 18, 312-318.

Snyder, S. A., \& Smail, R. A. (2009). Are all-terrain vehicle riders willing to pay trail user fees to ride on public lands in the USA? Tourism Economics, 15(2), 437451.

Song, H. (2011). Tourism Supply Chain Management. London: Routledge.

Song, H., Kim, J. H., \& Yang, S. (2010). Confidence intervals for tourism demand elasticity. Annals of Tourism Research, 37(2), 377-396. 
Song, H., \& Li, G. (2008). Tourism demand modelling and forecasting - A review of recent research. Tourism Management, 29(2), 203-220.

Song, H., Li, G., Witt, S. F., \& Athanasopoulos, G. (2011). Forecasting tourist arrivals using time-varying parameter structural time series models. International Journal of Forecasting, 27(3), 855-869.

Song, H., Li, G., Witt, S. F., \& Fei, B. (2010). Tourism demand modelling and forecasting: How should demand be measured? Tourism Economics, 16(1), 6381.

Song, H., Lin, S., Witt, S. F., \& Zhang, X. (2011). Impact of financial/economic crisis on demand for hotel rooms in Hong Kong. Tourism Management, 32, 172-186.

Song, H., \& Witt, S. F. (2006). Forecasting international tourist flows to Macau. Tourism Management, 27(2), 214-224.

Song, H., Witt, S. F., \& Li, G. (2009). The Advanced Econometrics of Tourism Demand. London: Routledge.

Song, H., Yang, S., \& Huang, G. Q. (2009). Price interactions between theme park and tour operator. Tourism Economics, 15(4), 813-824.

Southwick, R., Bergstrom, J., \& Wall, C. (2009). The economic contributions of human-powered outdoor recreation to the US economy. Tourism Economics, 15(4), 709-733.

Spencer, D. A. (2011). Getting personnel: Contesting and transcending the "new labour economics'. Work, Employment and Society, 25(1), 118-131.

Stabler, M. J., Papatheodorou, A., \& Sinclair, M. T. (2010). The Economics of Tourism $\left(2^{\text {nd }}\right.$ ed.). Abingdon: Routledge.

Stock, J. H. and M. W. Watson (2003). Introduction to Econometrics. London: Addison Wesley

Tang, S., Selvanathan, E. A., \& Selvanathan, S. (2007). The relationship between foreign direct investment and tourism: Empirical evidence from China. Tourism Economics, 13(1), 25-39.

Tapsuwan, S., Burton, M., \& Perriam, J. (2010). A multivariate probit analysis of willingness to pay for cave conservation: A case study for Yanchep National Park, Western Australia. Tourism Economics, 16(4), 1019-1035.

Thrane, C. (2005). Hedonic price models and sun-and-beach package tours: The Norwegian case. Journal of Travel Research, 43, 302-308.

Torraleja, F. G., Vazquez, A. M., \& Franco, M. J. B. (2009). Flows into tourist areas: An econometric approach. International Journal of Tourism Research, 11, 1-15.

Tremblay, P. (1998). The economic organization of tourism. Annals of Tourism Research, 25(4), 837-859.

Tribe, J. (2011). The Economics of Recreation, Leisure \& Tourism. Oxford: Butterworth-Heinemann.

Tribe, J., \& Xiao, H. (2011). Developments in tourism social science. Annals of Tourism Research, 38(1), 7-26.

Tung, G. S., Lin, C. Y., \& Wang, C. Y. (2010). The market structure, conduct and performance paradigm re-applied to the international tourist hotel industry. African Journal of Business Management, 4(6), 1116-1125.

Vila, N., \& Córcoles, M. (2011). Yield management and airline strategic groups. Tourism Economics, 17(2), 261-278. 
Vogel, M. P. (2009). The economics of US cruise companies' European brand strategies. Tourism Economics, 15(4), 725-751.

Wagner, J. (1997). Estimating the economic impacts of tourism. Annals of Tourism Research, 24(3), 592-608.

Williams, A. M., \& Shaw, G. (2011). Internationalization and innovation in tourism. Annals of Tourism Research, 38(1), 27-51.

Williamson, O. E. (1975). Markets and Hierarchies: Analysis and Antitrust Implications. New York: Free Press.

Wilson, K. (1998). Market/industry confusion in tourism economic analysis. Annals of Tourism Research, 25(4), 803-817.

Wong, K. K. F., Song, H., Witt, S. F., \& Wu, D. C. (2007). Tourism forecasting: To combine or not to combine? Tourism Management, 28, 1068-1078.

Wong, K. N., \& Tang, T. C. (2010). Tourism and openness to trade in Singapore: Evidence using aggregate and country-level data. Tourism Economics, 16(4), 965-980.

Wu, D. C., Li, G., \& Song, H. (2011). Analyzing tourist consumption: A dynamic system-of-equations approach. Journal of Travel Research, 50(1), 46-56.

Wu, D. C., Li, G., \& Song, H. (2012). Economic analysis of tourism consumption dynamics: A time-varying parameter demand system approach. Annals of Tourism Research, 39(2), 667-685.

Yang, S., Huang, G. Q., Song, H., \& Liang, L. (2009). Game-theoretic approach to competition dynamics in tourism supply chains. Journal of Travel Research, 47(4), 425-439.

Zhang, H. Q., Heung, V. C. S., \& Yan, Y. Q. (2009). Play or not to play - An analysis of the mechanism of the zero-commission Chinese outbound tours through a game theory approach. Tourism Management, 30, 366-371.

Zhang, H. Q., Kulendran, N., \& Song, H. (2010). Measuring returns on Hong Kong's tourism marketing expenditure. Tourism Economics, 16(4), 853-865.

Zhang, J., \& Jensen, C. (2007). Comparative advantage: explaining tourism flows. Annals of Tourism Research, 34(1), 223-243.

Zhang, X., Song, H., \& Huang, G. Q. (2009). Tourism supply chain management: A new research agenda. Tourism Management, 30, 345-358.

Zhang, Y., Qu, H., \& Guo, Y. (2011). A study of the agglomeration of China's convention industry: An economic and neo-economic geography framework approach. Tourism Economics, 17(2), 305-319.

\section{Authors' Biographies}

Haiyan Song, PhD, (hmsong@polyu.edu.hk) is chair professor of tourism in the School of Hotel and Tourism Management, Hong Kong Polytechnic University. Larry Dwyer, $\mathrm{PhD}$, is professor of travel and tourism economics, School of Marketing, University of New South Wales, NSW, Australia. Gang Li, PhD, is reader in tourism economics, School of Hospitality and Tourism Management, University of Surrey, UK. Zheng Cao is a PhD candidate in the School of Hospitality and Tourism Management, University of Surrey, UK. 